International Journal of Linguistics, Literature and Culture
Available online at https://sloap.org/journals/index.php/ijllc/
Vol. 5, No. 4, July 2019, pages: $25 \sim 33$
ISSN: 2455-8028
https://doi.org/10.21744/ijllc.v5n4.696

\title{
Correlation of Irires Noun towards Sago: An Ecolinguistic Study
}

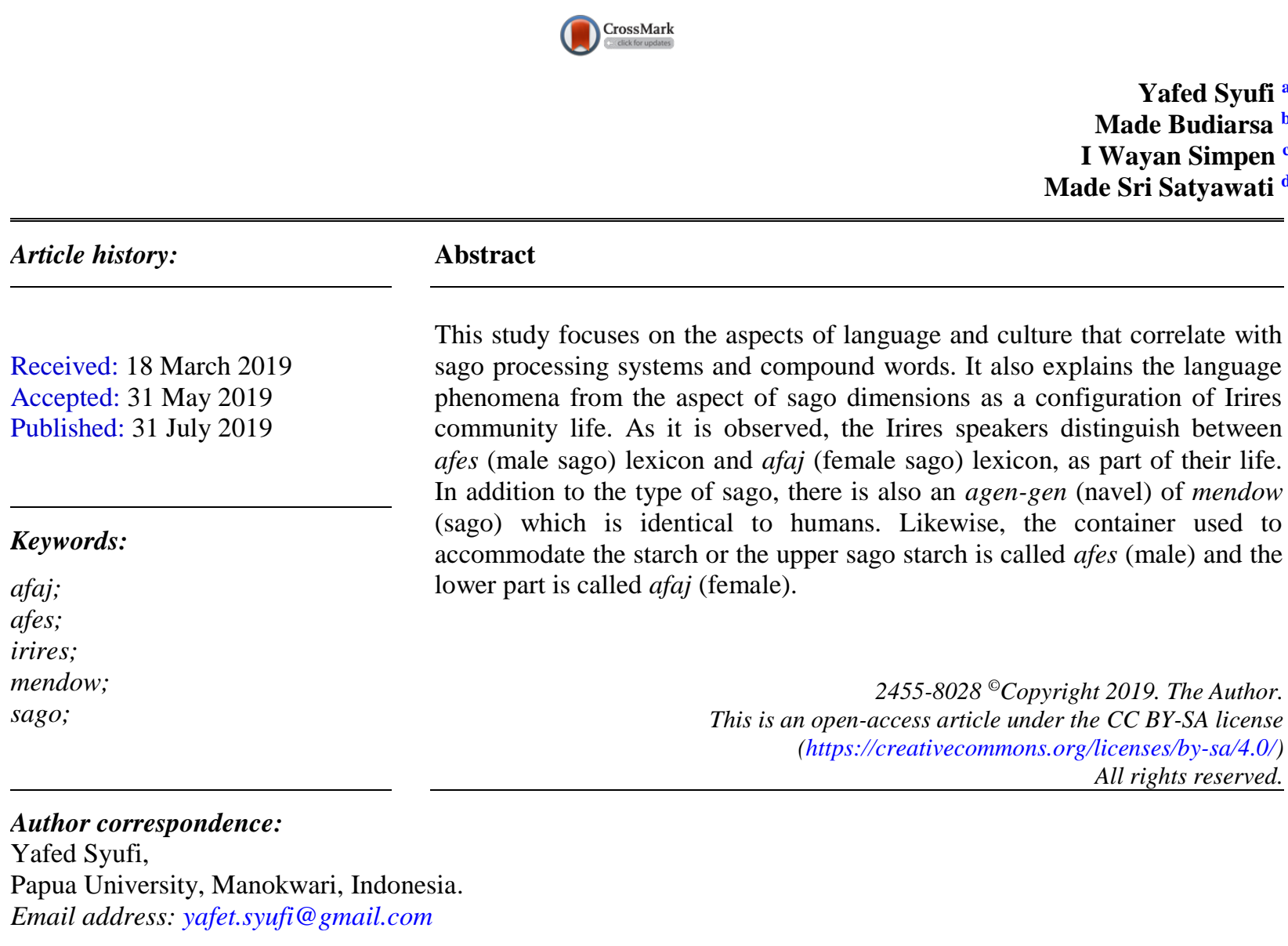

\section{Introduction}

The ethnic of Irires is an entity that inhabits the southern part of Tambrauw Regency. This regency is a part of West Papua Province. There are some previous researchers who have conducted research on languages in the Birds Head region. Some of them are Voorhoeve (1975); Silzer \& Heikkinen (1991); Welling (1985); Grimes (1996); Flassy \& Stokhof (1982); Berry \& Berry (1999). The subject of this paper is the language and cultural aspects of Irires community socio-culturally. The aspects of language are focused on non-human morphology and compound words in Irires language, in which these aspects experienced inversion in terms of forms. While seen from the cultural point of view, the study is focused on the aspects that correlate with various lexicons, such as afes (male sago) and afaj (female sago). Besides, the container for accommodating the upper sago starch is called afes (male),

${ }^{a}$ Papua University, Manokwari, Indonesia

${ }^{\mathrm{b}}$ Udayana University, Denpasar, Indonesia

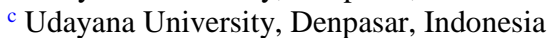

${ }^{\mathrm{d}}$ Udayana University, Denpasar, Indonesia 
while the lower part is called afaj (female). Sago also has an agen-gen (navel) that is usually correlated with fauna. Therefore, based on the perspective of the Irires community, it is observed that sago is being regarded as a form of a human, that has a navel, and starch that is beneficial to human life.

Language structure covers two branches of linguistics, namely morphology, and syntax. Morphology is a grammar that discusses the intricacies of morphemes, and words; while syntax is a grammar that discusses the intricacies of sentences (Soedjito, 2014). Irires language is spoken in Tambrauw Regency, West Papua Province. The number of Irires speakers is estimated to be 500 speakers. Irires language is regarded to be a minority language, compared to Mpur and Miyah languages. In other words, Mpur and Miyah languages are more dominant than Irires language, as the languages that are spoken by the people in Tambrauw regency. The distribution area of Mpur language is in the East Tambrauw covering Mubrani District and Amberbaken District, while Miyah language is in the area of northern Tambrauw. On the other side, Irires language is spoken in the southern Tambrauw area. Ecologically, the speakers of Miyah language inhabit the District of Senopi. They come from the areas of Siakwa, Ayae, Fumato, Ayapokiar, Rufiwies, Ruf, Atafrumek, Wayo, Syubun, Sikor, Ibe, Syunam, Banfot, Iwiam, Esyum, Imor, Hobiah, Ayawit, Aifatar, Yabuow, Ases, Asuon, Sofoetik, Frasayoh, Wismer, Ayamane, Hewi, Mawor, Sahae, Sisu, Tinggouw, Soon, Hohair, Ruriai, and Ifatkan (Syufi et al, 2019). The distribution area of the speakers of Mpur language is in the Districts of Kebar, Senopi, Mawabuan, Manekar, Kebar Timur, Kebar Selatan, and Mubrani, in which the number of the speakers of this language is very dominant (Syufi et al.,, 2019). While, the distribution of the speakers of Irires language only covers one district, that is Irires district.

\section{Materials and Methods}

The format of qualitative descriptive design has many similarities with a quantitative descriptive design. Therefore, a qualitative descriptive design can also be called a quasi qualitative or pseudo qualitative design (Bungin, 2011). The method is a way that must be implemented or applied, while the technique is a way to implement or apply the method (Sudaryanto, 2015). The method that is used in this study is a qualitative descriptive method, to describe the concept both theoretically and practically. Language is a nomenclature, so we must say that there are a number of different concepts (Saussure (1965) in Rochayah, 1996). According to Mayerthaler (1988), Morphology is the theory of word structure. The apparatus of morphological rules are defined by the nature of a (morphological) word of a language. The morphology that is the focus of this study relates only to nouns, verbs, and adjectives of Irires language. Nominal or commonly referred to as nouns are the construction of names or terms of all objects or everything that is subjected (Sugerman, 1999). Nouns, seen from the dimensions of the form, can be divided into two, namely the basic noun, and (2) derivatives (Rahardi, 1999). It is called basic nouns because it serves as the basis for the word-formation that occurs through morphological processes, therefore the basic noun is a construction, which is able to stand alone. This section is focused on the study of Irires nouns that correlate with sago. The Irires language nouns that are presented here are related to the sago processing system. In the sago processing, there are nouns that are more specific and unique. The specific and unique nouns are presented as follows: (1) sago stabbing wood, (2) sago halves of stem, (3) containers for storing sago starch, (4), navel of sago, and (5) mendow afes (male sago) and mendow afaj (female sago). In addition, sago shoots are classified into two parts, the first is afoi, and the second is the shoot that can be consumed mengogoh.

\section{Results and Discussions}

In Irires language, the noun memsung (sago stabbing wood or the wood for stabbing sago), is used to separate the sago stem into two halves. Memsung has a hard nature, so it is easy to separate the sago stem into halves. This stabbing wood is different from tugal or mecukur (wood stick) in Irires language, that is used in agriculture. The size of mecukur is smaller than memsung, that has a larger size. Both of these wood sticks are similar but different in use. The function of memsung is to separate the sago stem into two parts so that it becomes easy for the farmers to carry out their activities.

If the sago stem is more intact, the farmers would have difficulty in processing the sago. The nature of sago, compared with wood and bamboo is certainly different. Sago has a lot of fiber, so it is more easy to use memsung (wooden stick) to break the sago stem into two halves than to use axes or machetes. Meanwhile, wood and bamboo do not have fiber, so that it can be easily cut into two parts by using mesem (axes) or metow (machetes). Mecukur is 
generally used to dig through the soil to sow seeds such as mengukei (nuts), mecah (corn), merot (cucumbers), mefet (gourd), meney (banana shoot), mom (taro), cuttings such as mondef (cassava), moi (sweet potato), and meref (gedi's stems).

In addition to the above, there is also a smaller log which is called mergoh that is used to stab forest bananas and soft trees. These three entities memsug, mecukur, and mergoh are generally similar, but not the same in their utilization. The upper sago stem is called mendir gid, and the lower sago stem is called mendir mow. For the stems of bamboo and wood, the upper part of the wood stem is called awir gid, while the lower part of wood stem is called awir mow. For example, mer awir gid means the upper half of wood, and mer awir mow means the lower half of wood. The upper part of bamboo is called mendag awir gid, and the lower part of bamboo is called mendag awir mow. Basically, the container for storing pith/sago starch can be classified into two parts; the upper part is called afes (male), while the lower part is called afaj (woman). There is an indication that the container which is called women correlates with the heavy burden of a woman. As there is an idiom in Irires language that says ifaj $u k$ mowran aromat aso, means the woman has many burdens.

It is due to the nature of a woman that has to experience menstruation, pregnancy, childbirth, and breastfeeding. This analogy can be studied more deeply from various other fields of science, such as hermeneutics and sociocultural semiotics. Related to the container, it has both denotative and connotative meaning. Denotatively, it refers to as a container for storing sago starch. While connotatively, it may mean 1. an analogy as a woman who has a heavy burden of life, 2. as a balance factor between men and women so that they are more harmonious, or to be more complementary, 3. the factor of eastern culture which holds a perspective that women are lower class, like a container at the bottom to accommodate to sago starch.

In the practice of socio-cultural life of the Irires community, a woman must obey what is conveyed by her husband. A woman may not fight against her husband. What's more, is that this perspective is supported by a dowry that has been paid in full by her husband, so whatever is instructed by the husband, must be obeyed by a wife. From the point of view of other groups, this is discrimination. It is a cultural practice that deserves to be criticized because women and men must create harmony between the two parties without burdening each other. Why the container for accommodating the upper sago starch is not categorized as a woman, but men. It is perhaps that there is an ideological view of power denomination. The dominance of male power is more dominant so that it wraps the views of the Irires community in such away. The upper sago starch container is called mesef afes. The dominance of power is very dominant in an eastern culture which has the perception that women have a lower class group. This domination of power between men and women needs to be ratified again in order that women have the same degree as men.

Agen-gen (sago navel) is a meeting between the sago sheaths which converge. In other flora, there is no agen-gen (navel) lexicon, such as in meney (banana tree), moch (palm tree), and moft (fermented palm wine tree). Agen-gen (navel) of mendow (sago) is a linguistic phenomenon that is very meaningful in the lives of the Irires community. Navel is a very important element in the life of both humans and animals. In infancy, humans and animals need navels to transfer food from the mother to the child so that the baby develops flawlessly, as well as animals whose parents can transfer food for infants so that the baby can develop perfectly. In humans and fauna to adulthood, there is a navel. Therefore, there is a perception or belief among the society of Irires people that sago also has a navel, so that there is a specific lexicon called mendow agen-gen that refers to the navel of sago.

Universally, only fauna that has a navel, not flora like sago. Thus, it is a linguistic mystery that needs to be studied empirically and comprehensively, to give an understanding of the importance of linguistic anomalies about sago. There are still so many linguistic mysteries that are covered in the Iriries people's cognition as a laboratory space of life that is stored in its entirety. If it is not studied comprehensively, then what is stored in the minds of the speakers is not explored to be known by many people. What is stored in the minds of the speakers of Irires, such as mendow agen-gen (sago navel), if not well studied, then the language phenomena either implied or explicitly would not be revealed. Therefore, a lot of researches need to be conducted so that the knowledge stored in the mind of Irires people can be well narrated and documented for the advancement of science. Sago shoots can be classified into two parts, first (1) mendow afoi, a growing sago shoots, while mengogoh refers to the sago shoots that can be consumed. These sago shoots are usually cooked first to make them more crispy and delicious for consumption. The sago shoots, which is called mengogoh, if not cooked, will taste thick. So it is better to boil it first so that it is delicious for consumption. Mengogoh (sago shoots) can be consumed by all members of a family, without restrictions.

Mengogoh (sago shoots) should be taken to be cooked when the sago palm has just been cut down, so it tastes delicious for consumption. Besides, if the sago palm has borne fruit, the sago shoots to be consumed feel hard or no longer soft. The correct language can produce true knowledge about the world, it is because the smallest element of

Syufi, Y., Budiarsa, M., Simpen, I. W., \& Satyawati, M. S. (2019). Correlation of irires noun towards sago: An ecolinguistic study. International Journal of Linguistics, Literature and Culture, 5(4), 25-33. https://doi.org/10.21744/ijllc.v5n4.696 
language is a description of the smallest elements of the world of facts or atomic facts (Russel in Khoyin, 2013). Language and facts is a common thread that blends together so that it is easy to enter into human ratio to make it easier to discuss. The fact of language and reality that sago has a navel is a certainty of language. It is due to the general perception that only human and fauna that have a navel, not flora. But, it is a mystery of language, in which sago is analogous to humans that have a navel so that sago is said to be a tree of life for humans, flora, and fauna. Language can answer the empirical facts transmitted through the senses and human knowledge that are integrated with the surrounding environment. The relationship of meaning to reality may answer the various linguistic phenomena both a single word meaning or deictic words or other type of words that has a reference to more than one meaning that is very dependent on the speaker or the situation of the speaker, which is the same as the sago container for storing the sago starch. Morphologically, the compound word system in Irires language experienced inversion. The examples are presented in the following Table 1.

Table 1

Indonesian Language and Irires Language

\begin{tabular}{lll}
\hline Number & Indonesian Language & Irires Language \\
\hline 1 & Daun sagu (Sago leaves) & Mendow afei \\
2 & Batang sagu (Sago stems) & Mendow afag \\
3 & Pucuk sagu (Sago shoots) & Mendow afoi \\
4 & Pucuk sagu untuk dikonsumsi (The sago shoots for consumption) & Menggogoh \\
5 & Pelepah sagu (Sago fronds) & Mendow afef \\
6 & Duri sagu (Sago thorns) & Mendow afog \\
7 & Pati sagu (Sago starch) & Mendow afam \\
8 & Biji sagu (Sago seeds) & Mendow afed \\
9 & Lidi sagu (Sago sticks) & Moftpow \\
10 & Wadah untuk menampung pati sagu (Containers for storing sago starch) & Mesef \\
11 & Akar sagu (Sago roots) & Mendow afow \\
12 & Kulit sagu (Sago skin) & Mendow afoh \\
\hline
\end{tabular}

Based on the description of the compound words in Irires language, the word mendow means sago, while afei means leaf. Thus, the subordinate of the compound word mendow afei is the word mendow. Besides that, there is a more specific lexicon, i.e. the sago shoot for consumption is called menggogoh. The sago shoot is called mendow asus, while the sago shoot that grows is called mendow afoi. The boundary where sago can grow, or the end of growth. Sago stick is called moftpow. It is a language phenomenon that is owned by the socio-cultural community of Irires who inhabit the southern part of Tambrauw Regency. The moft pow (sago stick) based on the community perception is an entity that is identical to the stick from fermented palm wine. The naming is beyond the sago entity. Moftpow (sago palm stick) is a more specific lexicon. Moftpow (sago sticks) is usually used by children aged 4 to 7 years to be used as arrows when they play to shoot meed (lizards), mof (grasshoppers), mengei (forest bananas), and modef asus (cassava shoots). All of our knowledge, both knowledge about objects and knowledge about truth is based on recognition. The Irires community has the competence to be able to identify objects about sago in more detail because sago can answer their needs. Sensory data is personal to each person; what is immediately captured by someone's vision is not what is immediately captured by another person's vision (Russell in Asnawi, 2002). Experience and knowledge accompanied by the five human senses can easily capture and transfer the knowledge through speech so that the speaker can understand what he wants to say. Knowledge transfer is also needed to be accompanied by a more qualified intellectual so that the recipient can understand the message well, and is easy to apply. Scientific narratives that are expressed based on the logical thinking of the speakers about what is seen and experienced as long as their cognition is still able to store, and transfer the knowledge. The scientific language has its own characteristics namely informative, reproductive or intersubjective, and antiseptic. Informative means that scientific language expresses information or knowledge. This information or knowledge is stated explicitly, and clearly to avoid misunderstanding. Reproductive is a speaker or writer delivering the same information with information received by the listener or reader (Khoyin, 2013).

Language has a very important role in human life. There is no primitive or modern language, the most important is its function. With the existence of human language, the human may express what is in the surrounding natural environment. There are several lexicons that have been presented before, some are generic and specific. Therefore, it 
is worth getting to know the meaning of the lexicon. A lexicon is a vocabulary that is conceptualized as a wealth of words or vocabularies owned by language users. To understood more clearly, let's see the concept of lexicon offered by Kridalaksana (2008). According to him, there are three features of a lexicon: (1) language components that contain all information about meaning and use of words in language, (2) the wealth of words owned by a speaker or author, and (3) list of words arranged like a dictionary but with a brief and practical explanation.

Lexicon can be divided into two forms, namely the active form (active vocabulary) and passive form (passive vocabulary). The active form refers to the wealth of words that are used by someone actively, while the passive form refers to the wealth of words understood by someone but never or rarely used. The wealth of words possessed by the speakers of Irires needs to be passed down well to the younger generation so that the existence of the language remains well preserved. Specific lexicons are part of the passive lexicon because it is rarely used by the speakers unless there is direct interaction so that it turns into active lexicon. The lexicon of memsug (sago stab wood), the upper sago starch container which is called afes (male), the lower sago starch container which is called afaj (female), the consumable sago shoots which is called mengogoh, agen-gen (navel sago), the upper half of sago stem which is called mendir gid, and the lower half of sago stem which is called mendir mow are all part of the specific lexicon.

The more specific sago lexicon is part of the representation of Irires community life about the environment of sago. The structuring of the specific lexicon is based on the cognition or in the minds of the Irires community. The more specific lexicon of sago is a reflection of the life of the people of Irires which is closely related to sago. The mindset of the speaker that produces a particular culture in the lexicon owned by the community is related to human interaction with the environment. In the Whorf hypothesis, it is divided into two parts, namely the strong hypothesis and the weak hypothesis. Language has a central position, both languages form the way of thinking of the speakers and as a consequence language determines how they see the world. Language is used in every community by native speakers. The natural environment is where the language can live and develop so that the lexicon can live among the speakers of languages. Don't leave your language alone. The lexicon changes and persists based on the speaker and the environment in which the speaker interacts. Therefore, the sago environment must be well cared for so that there is sustainability of language for the next generation. Changes and shifts in language are determined by humans who maintain and care for their natural environment well so that humans may still exist to use their language based on what is observed. Human observation is real when the environment also supports. Environmental degradation also has implications for the language used by local people. The cognition of the speaker is strong if the environment is still well maintained. Environmental degradation has implications for the degradation of a language; therefore, there needs to be a balance between the environment and the use of the environment so that the two are complementary.

The wealth of the lexicon is the richness of language as a representation of living humans in reflecting life through a lexicon both generic and specific, depending on the time and space in which the speakers use the language. Observation of the generic and specific lexicons based on observations can be made while conducting research. Empirical research can reflect the experiences and knowledge of the speakers based on the lexicon that can be found when conducting research. The wealth of lexicons can be owned by the speaker and the speech partner about what they want to convey.

The lexicon can grow and develop if the environment is still well maintained so that each individual or group in speaking the language is easy to identify whether the lexicon still exists or has experienced a threshold of degradation. Specific lexicon, if there is good interaction; many lexicon features can be observed and studied to become a science that has empirical strength both practically and theoretically. Accuracy and maturity must be observed properly so that knowledge can provide prosperity for local residents. Language representation is a tangible manifestation of the representation of speakers and speech partners.

The issue of language phenomena related to the lexicon of sago needs to be studied systematically and comprehensively to show the features of the lexicon both generically and specifically so that it can be widely understood by other languages who want to learn the language. Specific lexicons need good study in order to become knowledgeable about language and also as a language owned by a particular community. A scientific study to show the perception of the community speakers about the activities that can be carried out by each community group. The meaning of the lexicon both generic and specific lexicon is very important to measure the competence of the speaker so that it can be understood that the lexicon still survives or has shrunk or even has become extinct. There is a relation of meaning between words and things where something indicates or points to another. All meanings rest on human needs so that humans are able to classify based on needs.

There is a correlation between human and needs, so that language is used to represent life to answer the needs to be achieved. Language solves the problems of human life through lexicons owned by each individual or group of speakers. Every word has meaning because words refer to something like what has been described sago. Language is

Syufi, Y., Budiarsa, M., Simpen, I. W., \& Satyawati, M. S. (2019). Correlation of irires noun towards sago: An ecolinguistic study. International Journal of Linguistics, Literature and Culture, 5(4), 25-33. https://doi.org/10.21744/ijllc.v5n4.696 
a nomenclature, so we must say that there are a number of different concepts (Saussure (1983) in Rochayah, 1996). The social fact about a number of lexicons, both generic and specific, is not disputed because it is conventional by the speech community. Each entity in the lexicon is described in more detail and some are universally elaborated. Nevertheless, this conventional gives a real reference to every speaker who wants to express something by choosing the right diction to convey the intention between the speaker and the speech partner. Language is a socially determined value system; it is not a collection of elements determined according to its substance (Saussure (1965) in Rochayah, 1996).

\section{Conclusion}

Language and culture is a unit that cannot be separated from each other. The representation of language and culture is a form of socio-cultural presence. Society has a language to reflect on the experience and knowledge it possesses. These knowledge and experience do not stand alone without the human senses and cognition possessed by every human entity. There are lexicons that are generic and some are specific, such as the sago lexicons. Especially in its classification, there are afes (male sago) and afai (female sago). Memsug (sago stabbing wood) which is a specific noun, that is different from tugal or meckur that is used in agriculture. Meckur or tugal is used to grow beans, yams, meney (bananas), and meras (sugar cane). Sago also has an agen-gen (navel) that is identical to humans who have a navel, in the analogy that sago is a representation of human life. Mendow (sago) is an entity that is always etched in the lives of Irires people in particular and the people of Papua in general. During famine, sago becomes food storage for the community. Sago does not need irrigation and fertilizers, it grows naturally. The mendow angen-gen lexicon has the meaning that the sago sheaths attached to the sago stem meet so that it is analogous to the navel. Agen-gen (navel) is the node of life, without the navel, there is nothing meaningful in life. Usually, the navel is found in the fauna, but sago has a navel is a language phenomenon that becomes the mysteries of life, especially those found in flora, more specifically in sago as a tree of life. Various flora varieties such as epiphytes can also live on sago trees. Sago is a gathering place for various types of fauna, such as yafi (sago beetles/rhynchophorus ferrugineus), meikuk (sago caterpillar/rhynchophorus ferrugineus). Sago beetles can live in sago as well as sago caterpillars. Another fauna that live in a sago environment is mos (frogs/ranae), meren afah (dragonflies/anisoptera), mof (grasshopper/et locusta). Furthermore, the description of the container used to store the starch or the upper sago flour is called afes (male), and the lower container is called afaj (female). There may be indications that the lower container called women correlates with how heavy a woman's burden, as there is an idiom in Irires language that says ifaj uk mowran aromat aso (women have many burdens). Semantically, this container has three meanings, namely: 1. denotatively as a container to store sago starch, 2. connotatively, women as a lower class composter socio-culturally, 3 . women have a heavier burden of life.

From the linguistic dimension, the compound words of Irires language experienced inversion in form. For example, daun sagu in Indonesian becomes mendow afei in Irires language, in which mendow (sago) serves as its subordinate, as can be observed in the table above. Linguistically, there are complex forms of words and some are singular. Complex forms are built by several morphemes, while single forms are built by one morpheme. In complex forms, especially in the form of derivatives, there is always original and basic form. The original form is different from the basic form, but there are also times when it is the same (Simpen, 2009). Language is a representation of the socio-cultural of a community, and more importantly, is that humans have five senses and intellectuals in helping to easily represent the natural environment. However, the more specific lexicon is not well understood by its speakers. Sago is also analogous to a human who has ajmeg mendow (the back) and mendow amen (the chest). The phenomenon of a language and its mystery is stored well in every mind of the speaker. Sago has a back is judged by the position of the person standing, And it also has a chest like a human, judged based on the position of the speaker who is standing close to the sago direction, meaning the front-facing to sago, thus it is analogous to human's chest.

\section{Conflict of interest statement}

The authors declared that they have no competing interest.

Statement of authorship

The authors have a responsibility for the conception and design of the study. The authors have approved the final article. 
Acknowledgments

The authors would like to thank the editor of IJJLC for their valuable time, support, and advice in completing the current study.

Syufi, Y., Budiarsa, M., Simpen, I. W., \& Satyawati, M. S. (2019). Correlation of irires noun towards sago: An ecolinguistic study. International Journal of Linguistics, Literature and Culture, 5(4), 25-33. https://doi.org/10.21744/ijllc.v5n4.696 


\section{References}

Asnawi, S. (2002). Teori motivasi dalam pendekatan psikologi industri dan organisasi.

Berry, R. J., Li, Z., Erickson, J. D., Li, S., Moore, C. A., Wang, H., ... \& Hong, S. X. (1999). Prevention of neuraltube defects with folic acid in China. New England journal of medicine,341(20), 1485-1490. https://doi.org/10.1056/NEJM199911113412001

Bungin, B. (2011). HM. 2010. Penelitian Kualitatif.

Grimes, J. (1996). On the failure to detect changes in scenes across saccades.

Khoyin, M. (2013). Filsafat Bahasa. Bandung: Pustaka Setia.

Kridalaksana, H. (2008). Kamus Linguistik edisi keempat. Jakarta: PT Gramedia Pustaka Utama.

Mayerthaler, W. (1988). Morphological naturalness. Karoma Pub.

Rahardi, R. K. (1999). Imperatif dalam bahasa Indonesia:: Kajian pragmatik tentang kesantunan berbahasa (Doctoral dissertation, Universitas Gadjah Mada).

Rochmah, S., \& Misbach, D. Rochayah. 1996. Individu dalam Masyarakat: Buku Teks Mengenai Psikologi Sosial. Pusat Pembinaan dan Pengembangan Bahasa. Departemen Pendidikan dan kebudayaan. Jakarta.

Russell, B. (1912, January). On the notion of cause. In Proceedings of the Aristotelian society (Vol. 13, pp. 1-26). Aristotelian Society, Wiley.

Saussure, F. D. (1965). Course in general linguistics, McGraw-Hilll Humanities. Social Sciences/Langua.

Saussure, F. D. (2013). Course in General Linguistics. 1983. London: Duckworth.

Silzer, P. J., \& Heikkinen, H. (1991). Index of Irian Jaya languages. Program Kerjasama Universitas Cenderawasih dan Summer Institute of Linguistics.

Simpen, I. W. (2008). Pelangi Bahasa Indonesia. Pustaka Larasan.

Soedjito, S. D. (2014). Morfologi Bahasa Indonesia.

Stokhof, W. A. L., \& Flassy, D. A. (1982). A recently discovered M (o) oi vocabulary in the national museum (Jakarta). Pacific Linguistics. Series A. Occasional Papers, (63), 53-130.

Sudaryanto, D. P. (2015). Metode dan aneka teknik analisis Bahasa [Method and technique of language study].

Sugerman, J. H. (1999). U.S. Patent No. 5,922,006. Washington, DC: U.S. Patent and Trademark Office.

Syufi, Y., Budiarsa, M., Simpen, I. W., \& Satyawati, M. S. (2019). The Portrait of Noken As A Manifestation of The Existence of Papuans. e-Journal of Linguistics, 13(2), 297-307.

Voorhoeve, C. L. (1975). Languages of Irian Jaya: checklist. Preliminary classification, language maps, wordlists. Pacific linguistics, Research School of Pacific and Asian Studies, The Australian National University.

Welling, M. S. (1985). German-English dictionary of plastics technology (Vol. 1). Pentech Press. 


\section{Biography of Authors}

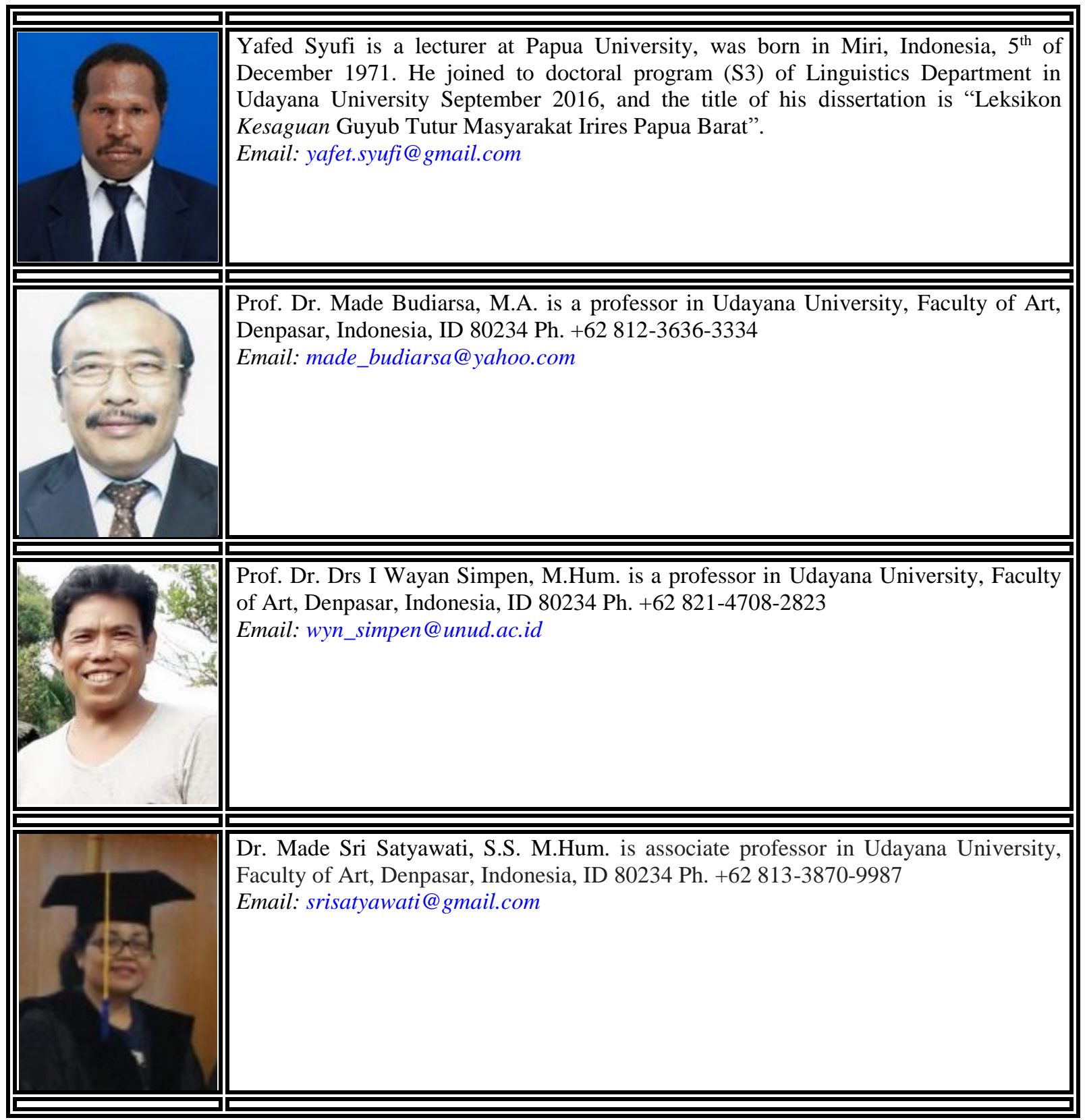

Syufi, Y., Budiarsa, M., Simpen, I. W., \& Satyawati, M. S. (2019). Correlation of irires noun towards sago: An ecolinguistic study. International Journal of Linguistics, Literature and Culture, 5(4), 25-33. https://doi.org/10.21744/ijllc.v5n4.696 